\title{
Escolarização de crianças com deficiência intelectual: problematizações sobre o currículo e os conteúdos escolares no ciclo de alfabetização
}

\author{
Amélia Maria Araújo Mesquita ${ }^{1}$ \\ José Rafael Barbosa Rodrigues² \\ Kelly Paixão de Castro 3
}

\begin{abstract}
RESUMO
Este artigo se propõe ao debate em torno da articulação entre o currículo e a educação especial, por meio da análise dos conteúdos de escolarização para alunos com deficiência intelectual (DI) matriculados no ciclo de alfabetização de uma escola pública da rede municipal de Belém/PA. Para tanto, baseado numa abordagem qualitativa, nos valemos da análise documental, tendo como fonte prioritária de dados os cadernos de alunos matriculados no ciclo de alfabetização do ensino fundamental. Com base nos cadernos, identificamos que há distinção entre os conteúdos e/ou atividades para crianças com e sem deficiência. A partir desse dado identificamos convergências e divergências que constituem o processo de escolarização: sobre os aspectos convergentes foi perceptível o investimento das professoras em garantir o desenvolvimento da alfabetização linguística e matemática, componentes curriculares hegemônicos no currículo dessa etapa de ensino. A despeito disso, a forma como o conteúdo é apresentado e o nível de complexidade das atividades vinculadas aos conteúdos se diferencia para alunos com e sem deficiência intelectual. Conclui-se que o processo de escolarização pra alunos com deficiência intelectual é marcado por intencionalidade pedagógica, mas a própria intencionalidade pedagógica no processo de alfabetização ainda se gerencia por mecanismos pouco propositivos às possibilidades de aprendizagem desse público. As fragilidades encontradas no processo de seleção/flexibilização curricular apresentado aos alunos com DI, em forma de conteúdos de escolarização, evidencia que é necessário ainda avançar nas pesquisas que aproximem educação especial e os estudos curriculares.
\end{abstract}

Palavras-chave: Currículo. Conteúdos de escolarização. Inclusão de alunos com deficiência.

\footnotetext{
1 Doutora em Educação pelo Programa de Pós-Graduação em Educação PPGED/ICED/UFPA. Docente da Universidade Federal do Pará, Belém, PA, Brasil. Orcid iD: https://orcid.org/0000-0003-4630-116X.E-mail: amelia.mesquita05@gmail.com

2 Doutorando do Programa de Pós-Graduação em Educação PPGED/ICED/UFPA, Belém, PA, Brasil. Orcid iD: https://orcid.org/0000-0001-5893-885X. E-mail: rafaelrodrigues92@outlook.com

3 Graduada em Pedagogia pela Universidade Federal do Pará, Belém, PA, Brasil. Orcid iD: https://orcid.org/0000-0003-0489-1608. E-mail: paixao19922@gmail.com
} 


\title{
Schooling of children whith intellectual disability: problems about the school
}

\author{
curriculum in the literacy cycle
}

\begin{abstract}
This paper proposes a discussion between the special education and the school curriculum, through the analysis of the contents of schooling to students with intellectual disability (ID), enrolled on the literacy cycle of a public school from the municipal system in Belem-Para. For that, based in qualitative approach we resort to documental analysis having as priority source the students' notebooks from literacy cycle of basic education. Based on the notebooks, we identify that there are distinctions between contents and/or activities for children with and without disability. From this data, we identified divergences and convergences that constitutes the schooling process: about the converging aspects, it was noticeable the teachers' investment in developing language and mathematical literacy, hegemonic curriculum components of this teaching stage. However, the way content is presented and the level of complexity of activities linked to content is different for students with and without intellectual disability. It is concluded that the schooling process for students with intellectual disability is marked by pedagogical intentionality, but the literacy process itself is still managed by not affirmative mechanisms to the learning possibilities for this public. The weaknesses founded in the curriculum selection/flexibilization process introduced to students with ID in schooling contents form evidence that it is still necessary advance in researches that approach special education and curriculum studies.
\end{abstract}

Keywords: Curriculum. Schooling contents. Inclusion of students with disability.

\section{Escolarización de niños con discapacidad intelectual: problematizaciones sobre el currículo y el contenido escolar en el ciclo de alfabetización}

\section{RESUMEN}

Este artículo se propone debatir sobre la articulación entre el plan de estudios y la educación especial, a través del análisis de los contenidos de escolarización para estudiantes con discapacidad intelectual (ID) matriculados en el ciclo de alfabetización de una escuela pública en Belém / PA. Por lo tanto, con base en un enfoque cualitativo, utilizamos el análisis de documentos, teniendo como fuente prioritaria de datos los cuadernos de estudiantes matriculados en el ciclo de alfabetización de la escuela primaria. Con base en los cuadernos, identificamos que hay una distinción entre contenido y/o actividades para niños con y sin discapacidades. A partir de estos datos identificamos convergencias y divergencias que constituyen el proceso de escolarización: en los aspectos convergentes se notó la inversión de los docentes para garantizar el desarrollo de la alfabetización lingüística y matemática, componentes del currículo hegemónico en el currículo de esta etapa de enseñanza. A pesar de esto, la forma en que se presenta el contenido y el nivel de complejidad de las actividades relacionadas con el contenido difiere para los estudiantes con y sin discapacidad intelectual. Se concluye que el proceso de escolarización para los estudiantes con deficiencia intelectual está marcado por la intencionalidad pedagógica, pero la 
intencionalidad pedagógica en sí misma en el proceso de alfabetización todavía se maneja mediante mecanismos no proposicionales a las posibilidades de aprendizaje de este público. Las debilidades encontradas en el proceso de selección / flexibilización curricular presentado a los estudiantes con ID, en forma de contenido escolar, muestra que se necesita más investigación para acercar la educación especial a los estudios curriculares.

Palabras clave: Currículum. Contenidos escolares. Inclusión de estudiantes con discapacidad.

\section{Introdução}

Se o conhecimento escolar permanece como um objeto incontornável da agenda política contemporânea (GABRIEL, 2013), do mesmo modo, discutir os processos de seleção e organização dos conteúdos de escolarização para pessoas com deficiência, seja em sua dimensão prescritiva ou prática, revela-se como urgente e necessária para continuarmos apontando para os caminhos da democracia, da igualdade e dos direitos humanos.

A inclusão de pessoas com deficiência no ambiente da escola regular faz com que professores e professoras da educação básica tenham a necessidade de desenvolver estratégias de mediação afim de os alunos com demandas físicas, motoras, intelectuais e globais específicas acessem o currículo regular das salas comuns. Dentre estas especificidades, algumas áreas apresentam maior dificuldade nesse processo, como ressaltam Pletsch, Mendes e Hostins $(2016$, p. 7) ao afirmarem que:

[...] apesar dos avanços acadêmicos-científicos no campo da Educação Especial, ainda enfrentamos enormes desafios na produção do conhecimento; no que se refere, sobretudo, ao processo de escolarização de alunos com deficiência intelectual, múltiplas e outras condições mais severas, que exigem práticas pedagógicas e curriculares diferenciadas.

Na tentativa de orientar e auxiliar os docentes da educação básica para mediar o acesso de alunos com deficiência ao conhecimento escolar, o Pacto Nacional pela Alfabetização na Idade Certa (PNAIC) no caderno um, que trata sobre currículo na perspectiva da inclusão e da diversidade, ressalta-se ao receber um aluno público-alvo da Educação Especial em sala, 
este deve "buscar formar-se para atender à demanda criada por essa inclusão, e garantir o acesso, a participação e a aprendizagem desse e dos demais alunos, conforme estabelece a Constituição Federal" (BRASIL, 2012, p. 57). Este, assim como os demais cadernos, orienta para o desenvolvimento e execução de estratégias práticas, encaminhando os docentes ao trabalho do conteúdo curricular sendo-o comum a todos, mas contemplando as diferenças durante o processo de ensino-aprendizagem.

Diante destas questões, entendemos a necessidade de olhar para a escola como um ambiente de estudo e análise por sua ampla demanda e seu papel na redefinição do contexto social atual (MENDES, 2004), assim o presente trabalho é parte do resultado da pesquisa "Mapeando o currículo no contexto da inclusão: os conteúdos para as crianças com deficiência dos anos iniciais do ensino fundamental", cujo objetivo é analisar qual tipo de conhecimento está sendo disponibilizado para os estudantes com deficiência matriculados nos anos iniciais de escolas públicas do município de Belém/PA.

Especificamente, trazemos para este texto o recorte dos dados sobre quais conteúdos estão sendo disponibilizados no processo de escolarização de alunos com deficiência intelectual matriculados no ciclo de alfabetização (três primeiros anos do ensino fundamental), e com isto, suas repercussões no processo de inclusão destes sujeitos, problematizando a função a qual tais conteúdos assumem na escolarização destes estudantes, no processo de aprendizagem destes conteúdos.

Para a apresentação dos resultados estruturamos o artigo em três partes: os caminhos metodológicos, os aportes teóricos e os dados empíricos acompanhados das análises dos resultados.

\section{Caminhos metodológicos}

A pesquisa sobre escolarização de alunos com deficiência matriculados em escolas regulares de ensino exige um olhar contextualizado e sensivel de modo a não produzir culpabilização nos sujeitos que estão na 
ponta desse processo (professores e alunos). Nessa perspectiva, esta pesquisa se desenvolveu sob uma abordagem qualitativa que segundo Gamboa (2007, p 61) "proporciona a busca de novas alternativas para 0 conhecimento de uma realidade tão dinâmica e polifacética como a problemática estudada".

A pesquisa foi realizada em uma escola da rede municipal de Belém, considerada referência na rede. Os dados foram coletados nos anos de 2017 e 2018 em turmas do $2^{\circ}$ e $3^{\circ}$ ano que possuíam alunos com deficiência intelectual matriculados. Ressalta-se ainda, a ausência de dados do $1^{\circ}$ ano em função de não atender ao critério de matrícula de aluno com DI na turma.

A pesquisa foi realizada por meio da análise documental, tendo por fonte prioritária de dados os cadernos de alunos nos anos iniciais do ensino fundamental $\left(1^{\circ}\right.$ ao $5^{\circ}$ ano). Considerando o recorte deste artigo, aqui trabalharemos apenas com os dados das turmas que compõem o I Ciclo do ensino fundamental (nesse caso, $2^{\circ}$ ao $3^{\circ}$ anos), constituindo o ciclo de alfabetização.

Cabe destacar que os cadernos escolares, vêm sendo utilizados de diferentes formas, a depender das áreas e objetos de pesquisa os quais servem como fonte, sendo-lhes atribuídos termos como "fonte histórica", "objeto gráfico", "objetos/fonte de pesquisa" (MIGNOT, 2008); "fonte primária" e "fonte histórico-educativa" (GVIRTZ; LARRONDO In MIGNOT, 2008).

Ao acessar os cadernos, enquanto fonte documental primária usados pelos alunos na sala regular no primeiro ciclo, esses registros foram fotografados respeitando a sequência de datas de cada caderno, por isso este trabalho se refere aos cadernos como fonte primária, mas faz uso de dados em forma de fonte secundária ou representação (Imagem/fotografia). No momento seguinte ao registro em ordem cronológica - forma de registro mais frequente nos cadernos usados em sala de aula - os dados foram agrupados e reorganizados, primeiro por disciplina (conforme a estrutura curricular da Rede) e depois por eixo temático 
(agrupamento de conteúdos sugerido nas diretrizes curriculares do município).

Foram fotografados cadernos de alunos com DI e de alunos sem deficiência de forma a identificar e analisar os conteúdos que constituem o processo de escolarização.

Seguindo as orientações de Bardin (2009), apresentamos, a seguir, algumas categorias para alcançar os principais objetivos da análise de conteúdo, sendo: 1) a superação da incerteza (busca assegurar que os elementos que o pesquisador julgou ver nas mensagens estão de fato presentes) e 2) o enriquecimento da leitura (busca superar leituras superficiais e garantir uma análise mais produtiva). Estas categorias devem colaborar com o intuito de oferecer aos textos atenção em sua totalidade, bem como as variações da "frequência de presença (ou de ausência) de itens de sentido" (BARDIN, 2009, p. 38-39).

Diante disso, usamos algumas classificações simples como: as disciplinas (componentes das áreas de conhecimento escolar) encontradas em destaque nos cabeçalhos dos cadernos ou a partir da descrição do conteúdo e atividade proposta; conteúdos (parcelas do conhecimento elaborado); e atividades (conjunto de estratégias e práticas metodológicas, didaticamente desenvolvidas para o ensino de determinado conteúdo).

Fazemos uso do referencial teórico para tratar do currículo a partir da análise do conteúdo presente nos cadernos de alunos, nos aproximando de um dos critérios de estudos adotados por Andrés e Zamora (2013), "o currículo prescrito versus o currículo ensinado, para compreender o currículo escolar na prática" (apud MIGNOT, 2008. p. 36), utilizando dos cadernos como fonte primária e/ou objeto/fonte de pesquisa e nos referindo a estes como documentos pedagógicos, em virtude de expressar parte do que a escola planeja ensinar na sala regular dos anos iniciais do ciclo de alfabetização.

Vale esclarecer, os cadernos utilizados para as fotografias foram disponibilizados pelas professoras das turmas. Para cada ano de escolarização há um caderno de aluno com DI e dois cadernos de alunos 
sem deficiência. Pedimos às professoras a disponibilização dos cadernos de alunos mais assíduos, de forma que pudéssemos acessar o maior número possível de conteúdos e atividades registradas. Tanto no ano de 2017 quanto no ano de 2018 os cadernos foram fotografados entre os meses de outubro e novembro. Para as turmas do $2^{\circ}$ e $3^{\circ}$ anos (anos que compõem o ciclo de alfabetização) tivemos acesso a seis cadernos, totalizando 590 folhas fotografadas.

A partir desses dados, e no cotejamento com o referencial teórico, partimos para as discussões e análises da pesquisa.

\section{Notas sobre currículo, conteúdos escolares e escolarização de alunos com deficiência intelectual}

A educação, enquanto um direito público subjetivo, é garantido pela Constituição Federal de 1988, e resguardado em forma de educação escolar pública sob obrigação do Estado, pelo Art. $4^{\circ}$ da Lei de Diretrizes e Bases da Educação Nacional - LDB, tendo por finalidade conforme o Art.22, "[...]desenvolver o educando, assegurar-lhe a formação comum indispensável para o exercício da cidadania e fornecer-lhe meios para progredir no trabalho e em estudos posteriores" (BRASIL, 1996).

Com isso, tal como defende Cury (2002), a educação básica torna-se um conceito, que remete a um direito do cidadão, e uma obrigação do Estado em atender esta demanda de forma qualificada. "E tal o é por ser indispensável, como direito social, a participação ativa e crítica do sujeito, dos grupos a que ele pertença, na definição de uma sociedade justa e democrática" (CURY, 2002, p.170).

Tendo estas prerrogativas como plano de fundo, destacamos a escolarização enquanto um direito inalienável de todos os cidadãos brasileiros, garantido pelo dispositivo legal, mas historicamente negado a determinados grupos sociais, os quais nos últimos anos tem passado por consideráveis processos de modificação. 
Desde os anos 1990, a inclusão de pessoas com deficiência no Brasil segue um alinhamento de internacionalização, motivada pela promulgação de um conjunto de cartas e declarações ${ }^{4}$ as quais têm influenciado o desenvolvimento de políticas públicas educacionais, com destaque às orientações curriculares, com vistas ao processo de escolarização de pessoas com deficiência.

A Política Nacional de Educação Especial na perspectiva da Educação Inclusiva (BRASIL, 2008, p.1), destaca:

Ao reconhecer que as dificuldades enfrentadas nos sistemas de
ensino evidenciam a necessidade de confrontar as práticas
discriminatórias e criar alternativas para superá-las, a educação
inclusiva assume espaço central no debate acerca da sociedade
contemporânea e do papel da escola na superação da lógica da
exclusão. A partir dos referenciais para a construção de sistemas
educacionais inclusivos, a organização de escolas e classes especiais
passa a ser repensada, implicando uma mudança estrutural e
cultural da escola para que todos os estudantes tenham suas
especificidades atendidas.

Argumentamos que o direito de escolarização está associado ao acesso aos conhecimentos próprios da escola. Saviani (2003), ao problematizar quais tipos de conhecimentos a escola deve ensinar, destaca a especificidade da educação enquanto atividade humana, atividade esta marcada pela transformação da natureza para sobrevivência da espécie. Para o autor, o homem, a fim de garantir sua existência, transforma a natureza e adaptando-a as suas necessidades, processo este o qual denomina de trabalho, a produção material. $O$ processo de trabalho, por sua vez a produção da existência humana, exige dos sujeitos um conjunto de saberes, habilidades e experiências, indispensáveis, como considera Saviani (2003, p.12):

Entretanto, para produzir materialmente, o homem necessita antecipar em ideias os objetivos da ação, o que significa que ele representa mentalmente os objetivos reais. Essa representação inclui o aspecto de conhecimento das propriedades do mundo real (ciência), de valorização (ética) e de simbolização (arte).

\footnotetext{
4 Destaca-se: Declaração Mundial sobre Educação para Todos, assinada em Jomtien na Tailândia em 1990;
} 
Duarte (2016), corroborando com este debate, tem defendido que a educação escolar e a prática pedagógica, enquanto um processo de mediação da totalidade da prática social, é uma formação mediadora entre a vida cotidiana, e as experiências não cotidianas de formação do gênero humano, incluindo a ciência, a arte, a filosofia. Sobre o conhecimento, Duarte (2016, p.67), define:

O conhecimento mais desenvolvido é aquele que permite a objetivação do ser humano de forma cada vez mais universal e livre. O critério é, portanto, o da plena emancipação humana. Em termos educativos, há que se identificar quais conhecimentos podem produzir, nos vários momentos do desenvolvimento pessoal, a humanização do indivíduo.

Em síntese, consideramos como finalidade deste estudo, garantir a aprendizagem dos conteúdos escolares enquanto um conhecimento elaborado, acumulado historicamente pelas ciências, pela arte e pela cultura, bem como outros conhecimentos, às crianças com deficiência intelectual, é uma tarefa que deve ser efetivada pela escola, por intermédio do ensino. O currículo escolar, portanto, é o espaço de efetivação destas experiências de aprendizagem, no qual os elementos destacados até aqui como indispensáveis para a efetivação da escolarização enquanto um direito social, deve ser garantido.

O debate sobre os currículos escolares, no entanto, necessitam de detalhamentos mais aprofundados, considerando a contingência política, cultural, social e econômica de nossos tempos.

\section{Currículo e conhecimento escolar}

Tal como argumentado por Santos (2009), não temos dúvidas de que a escola é um espaço de ensino-aprendizagem, ou ainda, para "fazer aprender alguma coisa a alguém" (ROLDÃO, 2007, p. 94). Mas, ainda que se tenha clareza de que a escola serve para que as futuras gerações aprendam "alguma coisa", e que esse "alguma coisa" é distinto dos saberes 
cotidianos, nos quais já tem acesso, vale questionar: qual a natureza dos elementos que compõem estas aprendizagens?

Ao lançarmos mão do questionamento em relação ao que a escola deve ensinar, entramos em uma seara bastante abrangente, cuja a qual inclui tanto aspectos políticos quanto pedagógicos, econômicos, sociais e culturais sobre a instituição escolar. O que inclui refletir sobre: as políticas de currículo desenvolvidas pelo estado, e seus processos de recontextualização/transformação curricular; os programas e projetos de gestão educacional; as concepções de formação docente; o perfil das avaliações da aprendizagem desenvolvidas, dentre outros elementos. Chamamos a atenção para este fato, a fim de enfatizar a importância que os processos de seleção e organização do conhecimento escolar tem para a escolarização.

De acordo com Sacristán (1998, p. 125), o termo currículo provém da palavra latina currere, referindo-se à carreira, a um percurso o qual deve ser realizado e, por derivação, a sua representação ou apresentação, guardando uma amplitude conceitual, estabelecendo-se a partir do contato com a realidade. Fazendo alusão ao conteúdo de planos e projetos de natureza educativa ou ainda à finalidade educativa com que estes projetos educativos são produzidos (SACRISTÁN, 1998). Diante de sua condição de produto humano, constituído por intencionalidades diversas, este percurso é marcado por elementos históricos e culturais no processo de escolarização de diferentes tempos e sociedades, sendo expresso por Sacristán como "O projeto seletivo de cultura, cultural, social, política e administrativamente condicionado, que preenche a atividade escolar e que se torna realidade dentro das condições da escola tal como se acha configurada" (SACRISTÁN 1988, p. 34 Apud CUNHA, 2011, p. 8).

O qual leva ao entendimento do currículo como processo, em virtude de, a partir das práticas pedagógicas e carga de significado, este não se estabelecerá como finito ou totalmente concluído (CUNHA, 2011). E é partir desta ideia que compreendemos o currículo escolar como um elemento construído a partir da influência do ambiente e das relações de ensino- 
aprendizagem entre os sujeitos. Assim, o currículo e sua apresentação é resultado das práticas de confecção e acabam por mediar a relações entre conteúdo e cultura. Demandando que se avalie as influências do contexto externo, como por exemplo, o exercício de práticas políticas, econômicas e sociais (SACRISTÁN; GÓMEZ 1998, p. 129).

Para este trabalho, acrescemos ao entendimento de currículo, em sua forma conceitual, alguns aspectos presentes em sua elaboração para um grupo específico de alunos com deficiência intelectual. Em razão de a particularidade dos alunos com deficiência intelectual estar na necessidade de flexibilização para desenvolver e fazer uso efetivo de suas habilidades intelectuais sem camuflar a importância dos aspectos sociais e biológicos. Juntos, esses aspectos devem nos recordar que, para efeito inclusivo, é necessário que o desenvolvimento cognitivo e social do aluno seja destaque no processo de escolarização. Entendemos o papel do currículo como elemento determinante de um desenvolvimento eficaz e, ao buscar identificar os conteúdos trabalhados com alunos portadores de deficiência intelectual, o temos conceitualmente a partir de algumas considerações, enquanto seletor de conhecimento inerente a todos os alunos $e$ pontualmente enquanto objeto da flexibilização de conhecimentos acessados pelos alunos com deficiência intelectual, algumas vezes expressos em planos individuais. Estes planos individuais, de acordo com Silva (2012, p. 5), são estruturados em dois níveis, a saber:

O primeiro refere-se às diferenciações/flexibilizações não significativas do currículo, isso é, as organizações didática, espacial, procedimental, metodológica, avaliativa e temporal da sala de aula; o segundo ligado na eliminação e na introdução de objetivos, de conteúdos, de metodologias e de recursos específicos.

Embora o plano para "identificação das necessidades educacionais específicas dos alunos, definição dos recursos necessários e das atividades a serem desenvolvidas" (BRASIL, 2010, p. 7), pelo Atendimento Educacional Especializado, como prescrito na Resolução CNE/CEB nº 4 de 2009, colabore nesse sentido, compreendemos que a força homogeneizadora e, consequentemente excludente do currículo necessita sofrer 
intervenção. Uma intervenção a qual fica a cargo das políticas públicas de educação e às certezas construídas no processo de formação dos profissionais da educação.

Sendo o conteúdo de escolarização de alunos com deficiência intelectual o nosso foco de investigação, delimitamos sua conceituação a partir da premissa cujo os conteúdos formam a base objetiva da instrução conhecimentos sistematizados e habilidades ambos referidos aos objetivos e viabilizados pelos métodos de transmissão e assimilação, ainda de acordo com o autor os conteúdos são:

O conjunto de conhecimentos, habilidades, hábitos, modos valorativos e atitudinais de atuação social, organizados pedagógica e didaticamente, tendo em vista a assimilação ativa e aplicação pelos alunos na sua prática de vida. Englobam, portanto: conceitos, ideias, fatos, processos, princípios, leis científicas, regras; habilidades cognoscitivas, modos de atividade, métodos de compreensão e aplicação, hábitos de estudo, de trabalho e de convivência social; valores, convicções, atitudes (LIBÂNEO, 1994, p. 128, grifo nosso).

O trecho grifado expressa de forma sintética um pouco do que é possível encontrar nos cadernos escolares, ressaltando sobre o conteúdo a partir das formas de organização do conhecimento elaborado, por conceitos e processos, mas também por modos e métodos que possam possibilitar a compreensão dos elementos curriculares levando em conta a inteireza da ação educativa e sua intencionalidade. Estando em consonância com os objetivos educativos os quais de acordo com Libâneo (1994, p. 120-121) estão pautados em ideais e valores presentes na legislação educacional nos conteúdos básicos das ciências e nas necessidades e expectativas de formação cultural exigida pela população majoritária da sociedade.

Os conteúdos curriculares em turmas regulares no ciclo de alfabetização do ensino fundamental - avanços e tensões na escolarização de alunos com DI

\section{As prescrições curriculares - condicionantes das escolhas curriculares}


O estabelecimento do ciclo de alfabetização, envolvendo os três primeiros anos do Ensino Fundamental, previsto do Plano Nacional de Educação (2014-2024), busca assegurar a universalização do Ensino Fundamental (meta 1) e o objetivo de alfabetizar todas as crianças brasileiras até 08 (oito) anos de idade (meta 5). Visa também que este processo de alfabetização ocorra de acordo com a perspectiva de letramento, colaborando para as crianças, público alvo do ciclo de alfabetização, vivenciarem experiências educativas com a finalidade de desenvolver a leitura e a escrita de forma significativa, fazendo uso destas habilidades no contexto social e cultural na qual estão inseridas, de forma autônoma. Dessa forma:

Um dos grandes desafios, na implementação do Ciclo de
Alfabetização, é o de assegurar às crianças o direito às
aprendizagens básicas nesse tempo de três anos. Isto pressupõe que
o protagonismo das ações esteja centrado nas crianças - seus
modos de ser, agir, pensar, expressar-se e aprender, o que exige,
necessariamente, que haja a revisão dos espaços e tempos
escolares, das propostas pedagógicas, do uso dos materiais, do
sistema de avaliação, das ofertas de apoio às crianças com
dificuldade, do investimento na formação inicial e continuada dos
professores, e nos vários aspectos que direta ou indiretamente
influenciam no direito de aprender das crianças [...] (BRASIL, 2013,
p.18).

Em termos locais, a Secretaria Municipal de Educação (SEMEC) ao propor Diretrizes Curriculares para $\bigcirc$ Ensino Fundamental para a Rede Municipal de Educação de Belém (RMEB) define suas perspectivas de trabalho para os ciclos de escolarização. O documento da rede de ensino do município apresenta as Áreas do Conhecimento a serem exploradas nos ciclos do Ensino Fundamental, compreendendo Linguagens, Ciências Humanas, Ciências da Natureza e Matemática. Ao dispor sobre os elementos curriculares a serem trabalhados em cada área do conhecimento, fica organizado por disciplinas. Dessa forma, para os anos iniciais do ensino fundamental, compreende o ensino das disciplinas de Língua Portuguesa, Arte e Educação Física, História, Geografia; Ciências Naturais e Matemática (BELÉM, 2012). 
Além das diretrizes, a rede municipal de Belém dispõe de um programa de formação para professores do ciclo de alfabetização denominado Expertise. O projeto tem materiais elaborados para colaborar com formação de professores e com a prática docente na rede pública municipal, entre os quais, os compêndios: "Expertise em Alfabetização: Formação de Professores", "Expertise em Alfabetização: Contribuição ao Planejamento Docente" e "Programa de Formação de Professores ECOAR: Alfabetização, Letramento e Matemática". O primeiro foi pensado para a formação de professores alfabetizadores, "para orientar o planejamento do professor e a avaliação da aprendizagem do aluno, a fim de consolidar as condições didáticas necessárias para a alfabetização das crianças" (BELÉM, 2012, p. 9). O segundo material, situado no campo da didática, apresenta textos motivadores sobre o processo de alfabetização e o desenvolvimento do ensino-aprendizagem direcionado aos professores, acompanhados de propostas iniciais para o planejamento semanal das atividades e sequências didáticas direcionadas ao campo semântico. No terceiro material, de título Alfabetização, letramento e matemática (2012), no qual encontramos além de textos motivadores, de natureza formadora de professores, uma descrição em itens dos conteúdos da alfabetização.

\section{As "escolhas" curriculares - os conteúdos priorizados no processo de escolarização do ciclo de alfabetização}

A seleção de conteúdos é processo marcado por tensões provenientes de diversas forças que operam no entorno do currículo. Aspectos como as prescrições, a formação de professores, as concepções sobre aluno, aprendizagem, ensino, são exemplos de forças que gravitam e de alguma forma determinam as escolhas curriculares.

Os registros marcados nos cadernos dos alunos das turmas do $2^{\circ}$ e $3^{\circ}$ ano do ensino fundamental de uma escola municipal de Belém revelam essas marcas de tensão, não apenas sobre os mecanismos para a garantia da escolarização de alunos com Dl, mas fundamentalmente, sobre a própria escola e a função que exerce no processo de formação das crianças. No 
processo de organização dos dados da pesquisa, produzimos a tabela a seguir que traz fortes indícios sobre as escolhas curriculares.

Tabela 1 - Distribuição de atividades registradas por turma/aluno sem e com deficiência do Ciclo I

\begin{tabular}{|c|c|c|c|c|c|c|}
\hline \multirow{3}{*}{$\begin{array}{l}\text { Disciplinas } \\
\text { identificadas }\end{array}$} & \multicolumn{6}{|c|}{$\mathbf{N}^{\circ}$ de páginas por disciplina } \\
\hline & \multicolumn{2}{|c|}{$\begin{array}{l}\text { Alunos } 2^{\circ} \text { ano } \\
\text { sem deficiência }\end{array}$} & $\begin{array}{c}\text { Alunos } 2^{\circ} \\
\text { ano } \\
\text { com } \\
\text { deficiência }\end{array}$ & \multicolumn{2}{|c|}{$\begin{array}{c}\text { Alunos } 3^{\circ} \text { ano } \\
\text { sem deficiência }\end{array}$} & \multirow{2}{*}{$\begin{array}{c}\text { Alunos } 3^{\circ} \\
\text { ano } \\
\text { com } \\
\text { deficiência } \\
\text { MR }\end{array}$} \\
\hline & K & $M$ & JK & $\mathbf{E}$ & I & \\
\hline Língua Portuguesa & 52 & 97 & 70 & 71 & 38 & 16 \\
\hline Matemática & 41 & 48 & 26 & 45 & 20 & 08 \\
\hline Ciências & 08 & 03 & 12 & 06 & 05 & 00 \\
\hline História e Geografia & 04 & 00 & 00 & 00 & 04 & 00 \\
\hline Artes & 02 & 03 & 00 & 04 & 07 & 00 \\
\hline $\begin{array}{l}\text { Total de páginas } \\
\text { registradas }\end{array}$ & 107 & 151 & 108 & 126 & 74 & 24 \\
\hline
\end{tabular}

Fonte: Acervo de pesquisa, realizada em 2018.

Conforme podemos perceber, as disciplinas de Língua Portuguesa e Matemática ganham status diante das demais disciplinas. Isso já revela, entre outras coisas, uma concepção de alfabetização marcada ainda por uma possível ideia de apropriação do código. Destaca-se, no entanto, que essa escolha não é fortuita, mas possivelmente consequência do programa Expertise, possuindo como foco as disciplinas de Língua Portuguesa e Matemática, projeto no qual as professoras estão implicadas mensalmente, tendo em vista a eficiência na avaliação em larga escala a qual os alunos do ciclo são submetidos.

Diante dos dados apresentados alguns elementos se destacam entre os registros. Com o objetivo de sintetizar os elementos identificados, apresentamos no quadro abaixo os conteúdos das disciplinas de Língua 
Portuguesa e Matemática ${ }^{5}$ registrados nos cadernos dos alunos do ciclo de alfabetização.

Quadro 1 - Conteúdos dos cadernos dos alunos do $2^{\circ}$ e $3^{\circ}$ anos com e sem deficiência

\begin{tabular}{|c|c|c|c|}
\hline \multicolumn{4}{|c|}{ CONTEÚDOS } \\
\hline \multicolumn{2}{|l|}{$2^{\circ} \mathrm{ANO}$} & \multicolumn{2}{|l|}{$3^{\circ} \mathrm{ANO}$} \\
\hline Alunos sem deficiência & $\begin{array}{l}\text { Alunos com } \\
\text { deficiência }\end{array}$ & Alunos sem deficiência & Alunos com deficiência \\
\hline \multicolumn{4}{|c|}{ Língua Portuguesa } \\
\hline \multicolumn{2}{|c|}{ ESCRITA E SELEÇÃO DE PALAVRAS } & \multicolumn{2}{|c|}{ ESCRITA E SELEÇÃO DE PALAVRAS } \\
\hline $\begin{array}{l}\text { Nomes próprios; } \\
\text { Escrita de letras e } \\
\text { palavras; Singular e } \\
\text { plural, e Acentuação. }\end{array}$ & $\begin{array}{l}\text { Escrita e identificação } \\
\text { das letras do alfabeto } \\
\text { (em sequência para } \\
\text { vogais e consoantes } \\
\text { ou alternadas para as } \\
\text { iniciais dos nomes dos } \\
\text { alunos, imagens de } \\
\text { objetos, frutas, } \\
\text { personagens e etc.); } \\
\text { Escrita e diferenciação } \\
\text { entre letra cursiva e } \\
\text { bastão; } \\
\text { Escrita de palavras na } \\
\text { modalidade } \\
\text { convencional e com } \\
\text { letras moveis } \\
\text { (Impressas); }\end{array}$ & $\begin{array}{l}\text { Gênero (masculino e } \\
\text { feminino); Substantivo, } \\
\text { adjetivo e artigo } \\
\text { (definido e indefinido) }\end{array}$ & $\begin{array}{l}\text { Escrita e identificação } \\
\text { das letras do alfabeto } \\
\text { (em sequência para } \\
\text { vogais e consoantes } \\
\text { ou alternadas para as } \\
\text { iniciais dos nomes dos } \\
\text { alunos, imagens de } \\
\text { objetos, frutas, } \\
\text { personagens e etc.); } \\
\text { Escrita e diferenciação } \\
\text { entre letra cursiva e } \\
\text { bastão; }\end{array}$ \\
\hline \multicolumn{2}{|c|}{ LEITURA, PRODUÇÃO E INTERPRETAÇÃO TEXTUAL } & \multicolumn{2}{|c|}{ LEITURA, PRODUÇÃO E INTERPRETAÇÃO TEXTUAL } \\
\hline $\begin{array}{l}\text { Escrita de palavras e } \\
\text { produção de frases; } \\
\text { Ortografia; } \\
\text { Leitura e interpretação. }\end{array}$ & $\begin{array}{l}\text { Leitura e escrita a partir } \\
\text { da associação entre } \\
\text { palavras e imagens; } \\
\text { Sinalização e } \\
\text { transcrição de } \\
\text { palavras do texto. } \\
\text { Diferenciação entre } \\
\text { letra (maiúscula e } \\
\text { minúscula); } \\
\text { Diferenciação entre } \\
\text { letra e numeral; }\end{array}$ & $\begin{array}{l}\text { Produção de texto; } \\
\text { leitura e interpretação } \\
\text { de texto. }\end{array}$ & $\begin{array}{l}\text { Leitura e escrita a partir } \\
\text { da associação entre } \\
\text { palavras e imagens; } \\
\text { Diferenciação entre } \\
\text { letra (maiúscula e } \\
\text { minúscula); } \\
\text { Produção textual } \\
\text { (escrita de frases e } \\
\text { texto curto). }\end{array}$ \\
\hline
\end{tabular}

5 Destaca-se que a opção por essas duas disciplinas se faz pelo número de registros nos cadernos dos alunos, já que as demais não foram priorizadas no processo de escolarização. 


\begin{tabular}{|c|c|c|c|}
\hline \multicolumn{4}{|c|}{ Matemática } \\
\hline \multicolumn{2}{|c|}{$\begin{array}{l}\text { SISTEMA DE NUMERAÇÃO DECIMAL, ARITMÉTICA E } \\
\text { GEOMETRIA }\end{array}$} & \multicolumn{2}{|c|}{$\begin{array}{l}\text { SISTEMA DE NUMERAÇÃO DECIMAL, ARITMÉTICA E } \\
\text { GEOMETRIA }\end{array}$} \\
\hline $\begin{array}{ll}\text { Sequência e posição; } \\
\text { Par e ímpar; } \\
\text { Dobro; } \\
\text { Adição, } \\
\text { Subtração, } \\
\text { Multiplicação; } \\
\text { Interpretação } \\
\text { resolução } & \\
\text { problemas (de } & \text { de baixa } \\
\text { complexidade); } \\
\text { Figuras e sólidos } \\
\text { geométricos. }\end{array}$ & $\begin{array}{l}\text { Sequência e posição; } \\
\text { Escrita de algarismos; } \\
\text { Relação entre numeral } \\
\text { e quantidade (com } \\
\text { diferentes formas de } \\
\text { representação). }\end{array}$ & $\begin{array}{l}\text { Agrupamentos do SND; } \\
\text { Adição, } \\
\text { Subtração, } \\
\text { Multiplicação, } \\
\text { Interpretação } \\
\text { resoluçãor e } \\
\text { problemas (de baixa } \\
\text { complexidade); } \\
\text { Figuras e } \\
\text { geométricos. }\end{array}$ & $\begin{array}{l}\text { Apresentação de } \\
\text { números naturais } \\
\text { (escrita); } \\
\text { Relação entre numeral } \\
\text { e quantidade (com } \\
\text { diferentes formas de } \\
\text { representação); } \\
\text { Agrupamentos do SND; } \\
\text { Par e ímpar; } \\
\text { Subtração; } \\
\text { Valores monetários; } \\
\text { Registro e medição da } \\
\text { passagem do tempo } \\
\text { (horas). }\end{array}$ \\
\hline
\end{tabular}

Fonte: Acervo de pesquisa, realizada em 2018.

Diante dos dados coletados, foi possível agrupar os conteúdos de Português e Matemática e "eixos temáticos". Em Língua Portuguesa, identificamos "escrita e seleção de palavras" e "leitura, produção e interpretação textual". Em matemática, identificamos "sistema de numeração decimal, aritmética e geometria". Observa-se que esses são assuntos comuns para todos os alunos das turmas de $2^{\circ}$ e $3^{\circ}$ ano do ciclo de alfabetização. Contudo, ao nos dedicarmos aos conteúdos e às atividades produzidas, começamos a observar distinção entre alunos com deficiência e alunos sem deficiência.

Os conteúdos de Língua Portuguesa vão ganhando grau de complexidade no ano de escolarização e entre anos para os alunos sem deficiência. Começam com a escrita de palavras e produção de frases e avançam para produção de textos e classificações e análise das classes gramaticais, conforme podemos observar na sequência de imagens das figuras a seguir. 
Figuras 1, 2, 3 e 4: Progressão dos conteúdos e tipo de atividade de Língua Portuguesa para alunos sem deficiência em turmas do $2^{\circ}$ e $3^{\circ}$ anos do ciclo de alfabetização
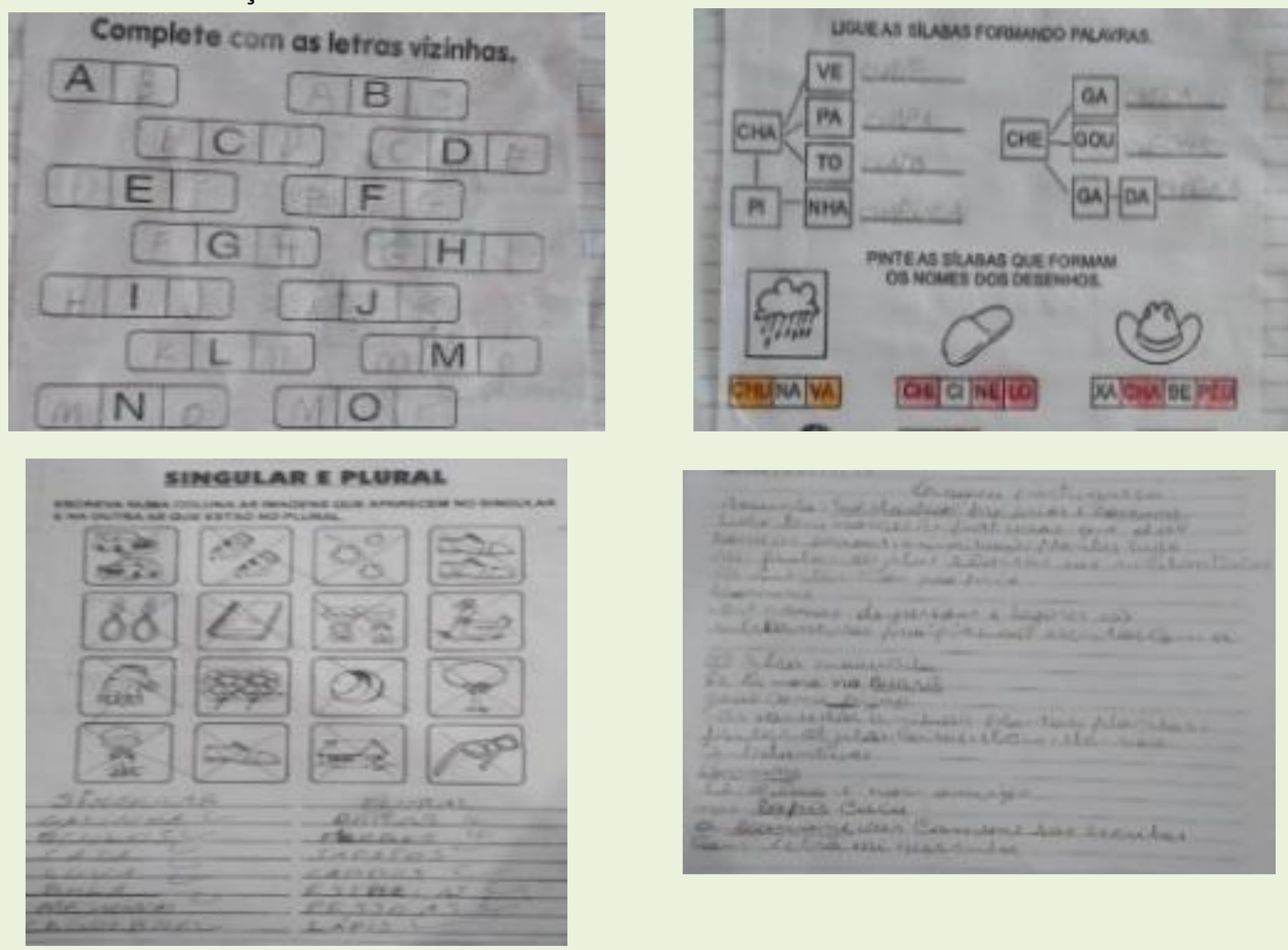

Fonte: Acervo da pesquisa, realizada em 2018.

Para os alunos com deficiência intelectual os conteúdos se restringem à escrita de palavras, identificação e associação de letras/palavras/figuras. Conteúdos os quais se repetem entre os anos, conforme os registros a seguir: 
Figuras 5,6,7,8: Progressão dos conteúdos e tipo de atividade de Língua Portuguesa para alunos com DI em turmas do $2^{\circ}$ e $3^{\circ}$ anos do ciclo de alfabetização
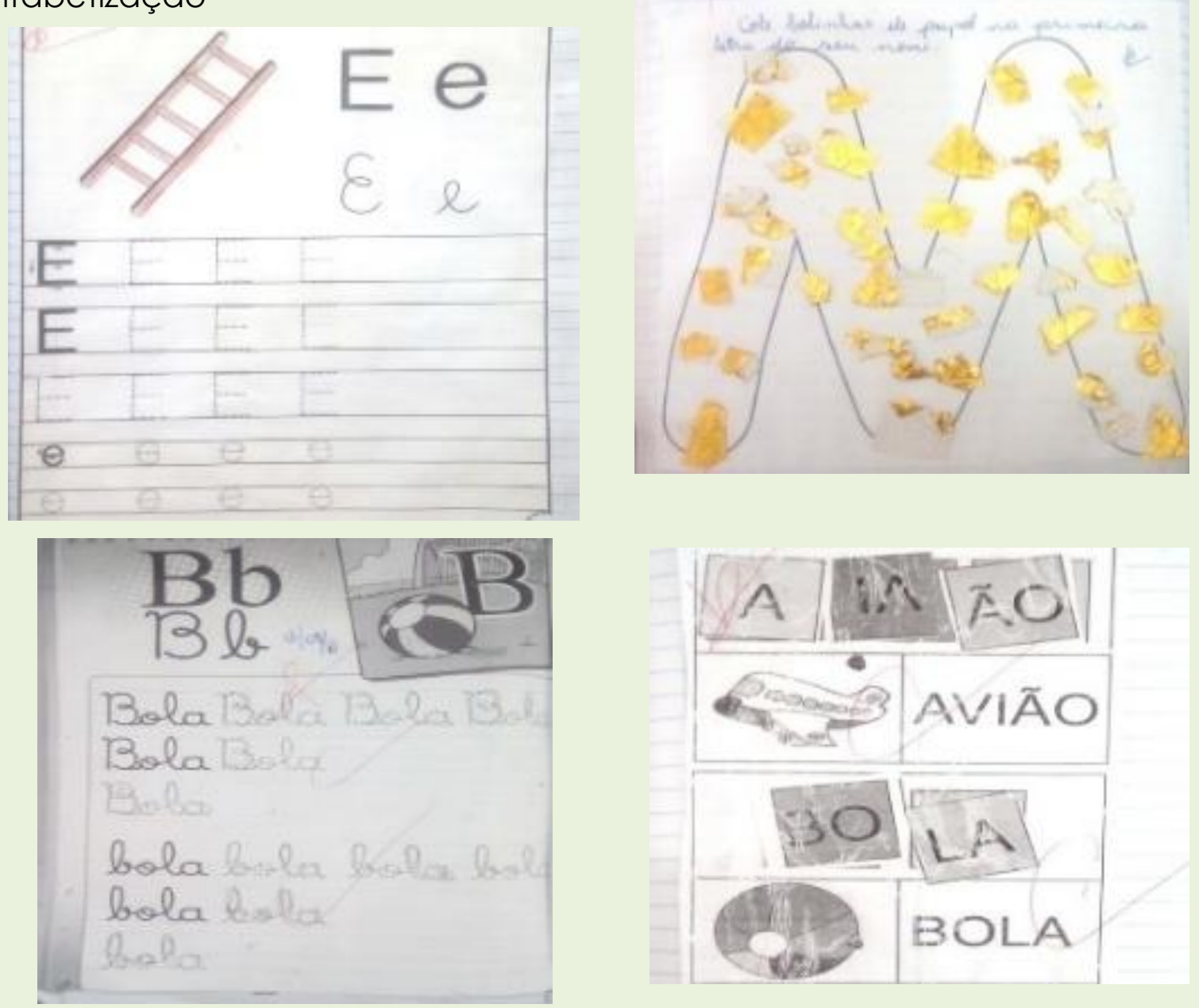

Fonte: Acervo da pesquisa, realizada em 2018.

Destaca-se, na passagem dos registros de dados de um caderno a outro um conjunto de elementos que se apontou, inicialmente pela quantidade, foram as atividades de prontidão. Para além dos registros identificados como conteúdo/atividade no quadro 1, foi registrado um total de 116 páginas de atividades motoras variadas, envolvendo no geral escrita mecânica; desenho, pintura e colagem. Como podemos observar nas imagens a seguir. 
Figuras 9, 10, 11, 12: Atividades para alunos com DI ( $2^{\circ}$ e $3^{\circ}$ anos)
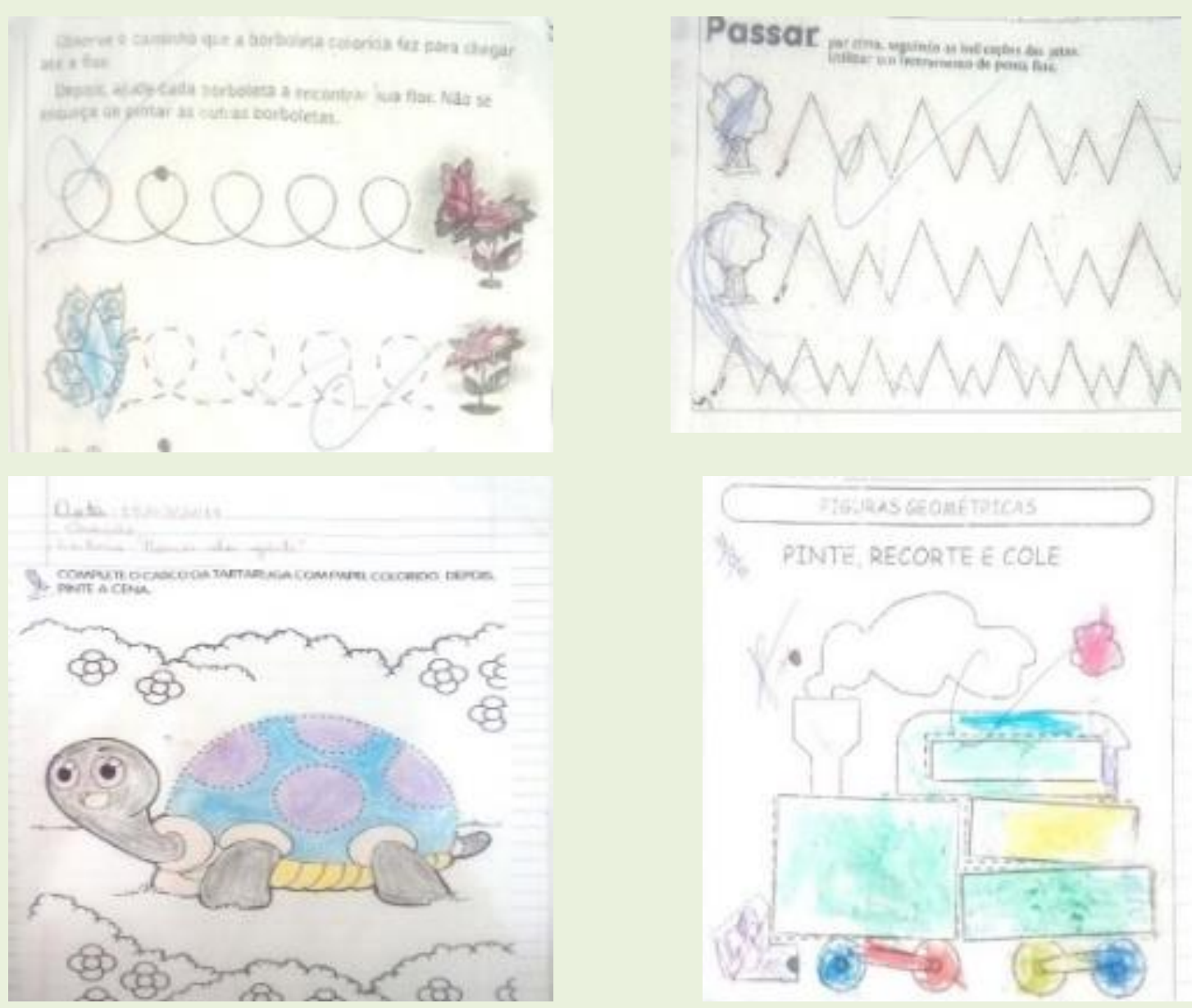

Fonte: Acervo da pesquisa, realizada em 2018.

A partir dos dados registrados nos cadernos, observa-se um desnível entre o tipo de atividade destinada aos alunos, implicados numa classificação com e sem deficiência, demarcando por si, estratégias de inclusão podendo gerar diferenciações negativas, mesmo sem que as professoras tenham tal intenção.

Essa mesma perspectiva também fica evidente nos registros de conteúdos e atividades referentes à Matemática.

Quando nos referimos ao conhecimento lógico matemático é importante ter em mente alguns pontos de grande relevância presentes no processo de ensino e aprendizagem durante a escolarização nos anos de alfabetização, como a introdução ao Sistema de Numeração Decimal (SND), Aritmética e Geometria, usualmente cobrados na resolução de 
problemas. Assim recorremos a organização em dois níveis distintos de conteúdo/atividade sobre o conhecimento matemático, buscando contemplar os registros referentes ao $2^{\circ}$ e $3^{\circ}$ anos do primeiro ciclo de alfabetização. Os itens são: Sequência e posição; Par e ímpar; Dobro; Adição, Subtração, Multiplicação, Figuras e sólidos geométricos.

Figuras 13,14,15,16: Progressão dos conteúdos e tipos de atividades de matemática para alunos sem deficiência $\left(2^{\circ}\right.$ e $3^{\circ}$ anos)
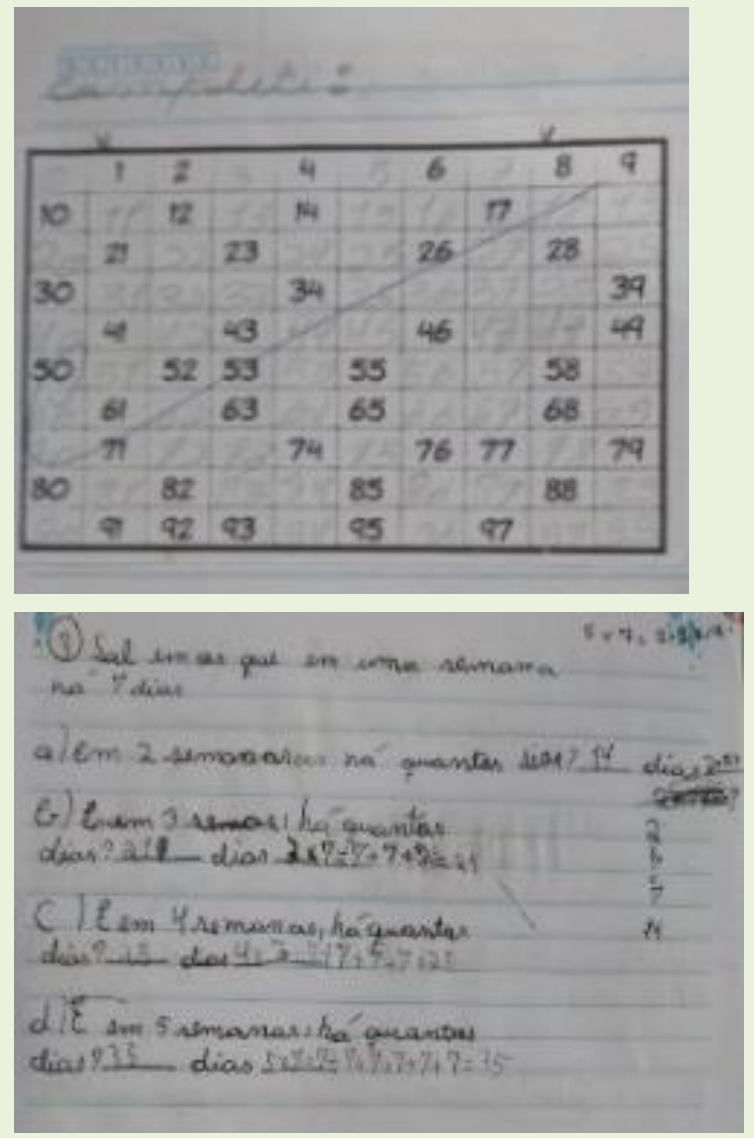

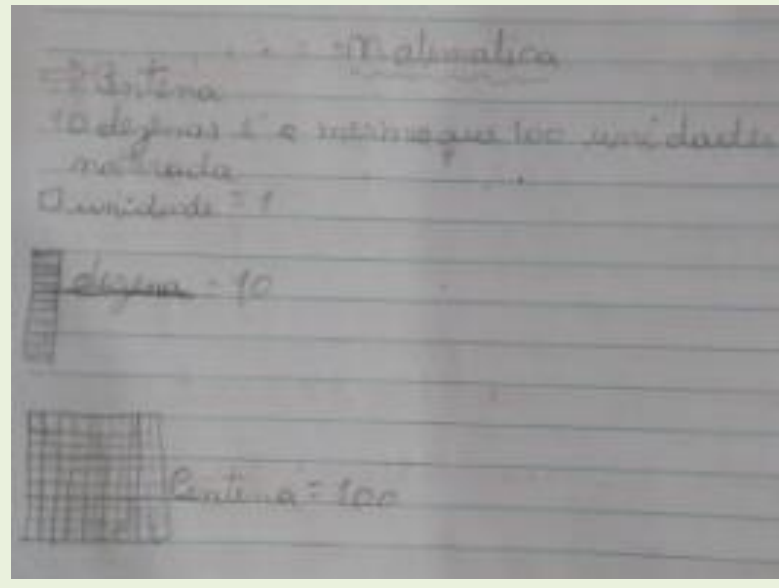

Fonte: Acervo da pesquisa, realizada em 2018.

Observa-se nos registros que os conteúdos vão avançando e as atividades vão ganhando dimensões mais complexas.

Quando comparamos o acervo disponibilizado ao aluno com DI, identificamos a seguinte situação. 
Figuras 17,18,19,20: Atividade para alunos com DI ( $2^{\circ}$ e $3^{\circ}$ anos)
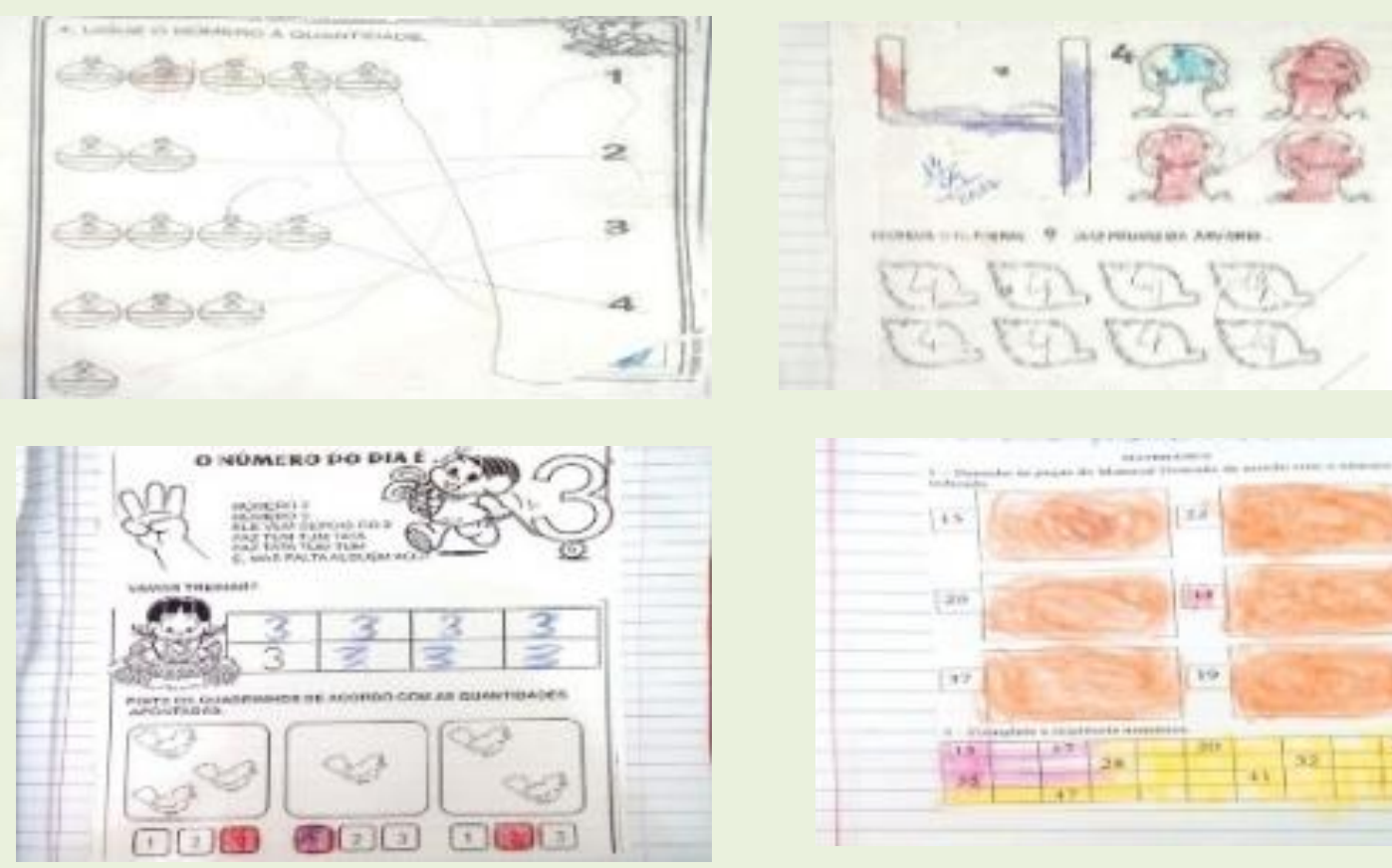

Fonte: Acervo da pesquisa, realizada em 2018.

Ainda que haja predominância de atividades sempre mimeografadas, e no caso para alunos com deficiência, apenas identifiquemos registros de atividade e não de conteúdos, e nessa área do conhecimento que também identificamos algum tipo de avanço no nível de complexidade de atividades para alunos com Dl, conforme podemos observar nas atividades de um aluno com DI matriculado do $3^{\circ}$ ano.

Figuras 24, 25, 26, 27: Conteúdo e atividade para aluno com DI ( $3^{\circ}$ ano)
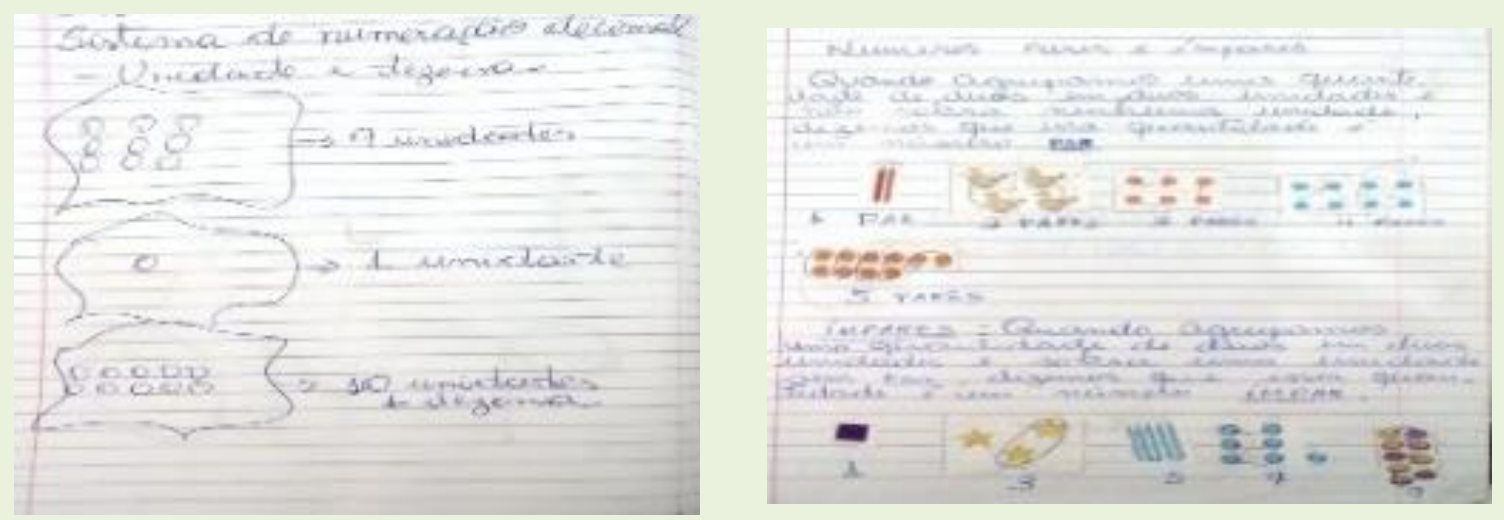

Fonte: Acervo da pesquisa, realizada em 2018.

Revista Exitus, Santarém/PA, Vol. 10, p. 01-31, e020082, 2020. 
No geral, há progressão no nível de complexidade a qual as turmas têm acesso. Em alguns momentos os conteúdos apresentados aos sujeitos sem e com deficiência tem elementos comuns e de proximidade.

Conforme podemos notar, há uma grande diferença entre os conteúdos trabalhados para os alunos com e sem deficiência distinguindo-se pelo grau de complexidade, referindo-se tanto à progressão no próprio ano, quanto entre anos. Para os alunos sem deficiência, os conteúdos reforçam a apropriação de conceitos e aplicação com 0 intuito de adquirir aprofundamento a medida que os alunos progridem na escolarização, contudo, para os alunos com deficiência intelectual os registros apontam para repetição em tipo e objetivo das atividades.

Embora Língua Portuguesa seja a disciplina com maior volume de registros é na disciplina de Matemática onde encontramos maior diversidade de conteúdos elaborados trabalhados com os alunos com deficiência intelectual. Mas em ambas as disciplinas as atividades propostas para os alunos com DI são muito marcadas pela prontidão, e sem continuidade das sequências didáticas.

\section{Problematizações sobre as "escolhas" curriculares e suas implicações no processo de escolarização}

Como já demarcado, os conteúdos escolares, enquanto um conhecimento específico, produzido em meio as correlações de força, tem sido um patrimônio cultural, artístico e científico historicamente negado a determinados grupos sociais. A luta histórica pela democratização da educação é também uma luta pelo processo de democratização na aprendizagem dos conteúdos elaborados e sistematizados em forma de conhecimento para todos, em especial, para os grupos sociais historicamente marginalizados, como as pessoas com deficiência intelectual.

Para uma melhor compreensão sobre nossos propósitos, e um melhor entendimento de nossos objetivos, definimos escolarização como: 
O processo e a paulatina produção de referências sociais tendo a escola ou a forma escolar de socialização e transmissão do conhecimento, como eixo articulador de seus sentidos e significados. Neste caso a nossa atenção estará voltada para o que temos chamado de "consequências" sociais, culturais e políticas da escolarização, abrangendo questões relacionadas ao alfabetismo, ao reconhecimento ou não de competências culturais e políticas dos diversos sujeitos sociais [...] (FARIA FILHO, 2002, p. 522).

Em um processo histórico a escolarização das pessoas com deficiência passou por transformações. Seja de ordem política/ideológica, ou mesmo de cunho filosófico, estas modificações acompanhadas do contexto social de um determinado período histórico, mudavam as características do trato dado a estas pessoas. Contudo, as diferentes formas de tratamento às pessoas com deficiência intelectual, ainda têm resíduos nas práticas atuais e na percepção da capacidade de aprendizagem desse grupo de sujeitos.

No que diz respeito à escolarização das pessoas com deficiência intelectual o quadro histórico é ainda mais precário, pois, por muito tempo o imaginário obtido era de algo quase impossível, a escolarização em turmas regulares de pessoas em situação de deficiência intelectual, em razão de entender-se algo sobre estas pessoas, elas não compreendiam de maneira alguma o que se propunha a ensinar, além disto, outra justificativa bastante usual era, os professores não estavam preparados para isto (SANTOS; SOUZA, 2011). Esses dois aspectos possivelmente circundam as práticas das professoras no processo de seleção dos conteúdos e definição das atividades, como evidenciamos na apresentação dos dados acima. Independentemente de termos superado a ideia de inclusão como mera socialização, se observa certo receio em avançar no nível de complexidade dos conteúdos quando destinados às crianças com deficiência intelectual, talvez por isso, em predomínio os conteúdos ficam limitados ao tipo procedimental, com foco nas funções motoras e associativas, como se essas fossem pré-requisitos para alfabetização.

Compreendemos que o processo de inclusão escolar de alunos com deficiência intelectual se dá desde modificações de grande porte, até a sensibilidade que o professor deve ter ao pesquisar ou criar estratégias 
metodológicas para a escolarização destes alunos, de forma a incluir estes nas atividades programadas na turma, porém, sempre devem ser respeitadas as suas individualidades e especificidades.

No contexto da escola investigada, e, portanto, da seleção feita pelas professoras, alguns aspectos precisam ser destacados: 1) no ano de 2017 houve a redução do quadro de professoras da educação especial na escola,- implicando na qualidade do trabalho colaborativo entre a sala regular e a sala de recursos multifuncionais; 2) o programa de formação de professores (Expertise) por se limitar a formá-los em Língua Portuguesa e Matemática, e por definir as sequências didáticas que devem ser trabalhadas mensalmente, acabaram por limitar o currículo a essas duas disciplinas, comprometendo $O$ direito de acesso dos alunos ao conhecimento de forma mais ampla e a própria ideia de alfabetização fica restrita a números e letras.

Nesse contexto, o respeito a individualidades e especificidades dos alunos com DI é produzido de forma intuitiva pelas professoras as quais buscam criar mecanismos dentro de suas possibilidades, mas sem a clareza das consequências que suas tentativas podem trazer na produção de mecanismos uma inclusão marginal.

Lunardi-Mendes e Silva (2014), enfatizam:

Os indivíduos possuidores de alguma deficiência assistem ao esgotamento de suas possibilidades de aprendizagem, uma vez que a própria dinâmica educativa solicita resultados que só podem ser atingidos ao apresentarem um suposto padrão considerado normativo. Portanto, inclusão escolar não pode se tratar apenas da colocação de indivíduos historicamente diferenciados e estigmatizados diante de um currículo que apresenta problemas graves de qualidade expressos pelos baixos níveis de aprendizagem que alcançam e altos níveis de evasão e repetência que proporcionam. Para que esse fato se materialize, a escola precisa enfatizar a reflexão e o diálogo, determinados pelo conhecimento, esclarecimento, isto é, por tudo aquilo que a cultura estabeleceu como verdadeiro na luta contra os mitos.

Ora, observa-se, a partir dos registros dos cadernos, de forma indiscriminada para alunos com e sem deficiência, que a cultura tradicional instituída historicamente ainda não cedeu espaço a uma nova forma de 
fazer educação. Nesse sentido, busca-se incluir num contexto pedagógicocurricular engessado numa prática educativa perenizada e que sempre foi pouco propositiva ao atendimento à diversidade.

Os registros nos cadernos dos alunos, embora indiquem divergências na forma como se destina e no que é destinado aos dois grupos de alunos produzidos, revelam acima de tudo, que a escola não altera seu status e modo de lidar e compartilhar o conhecimento produzido historicamente. Esse fica restrito ao simples, ao comum, ao pouco propositivo à produção de formas de pensamento autônomas e críticas.

A alfabetização não ganha uma dimensão ampliada, no sentido de leitura do mundo, fica restrita ao código e à gramática, aspectos com certeza importante, contudo, precisam sair da dimensão meramente procedimental.

Assim, emerge a necessidade dos sistemas educacionais se organizarem com o objetivo de prover meios adequados para atender às necessidades do alunado, favorecendo o desenvolvimento afetivo e cognitivo promovendo aprendizagem efetiva dos conteúdos escolares, "quebrando tabus" e diferentes formas de preconceito frente à diversidade (TELES, 2010, p. 27).

É nesta adequação a qual as instituições escolares necessitam fazer as alterações curriculares necessárias, por isto acreditamos que se o profissional de educação se encontrar apto para a realização de um novo projeto educativo, bem como a promoção das modificações curriculares e as adequações de novas metodologias, será possível a assimilação deste processo de ensino a todos os alunos, mesmo os com alguma limitação, como é o caso dos alunos com deficiência intelectual.

Sampaio (2005) argumenta que apenas a matrícula e uma reforma estrutural nas dependências da escola, bem como a utilização de diferenciações curriculares de pequeno porte nas turmas regulares não seria suficiente para a permanência deste aluno na escola, corrobora com a necessidade da utilização e criação novas metodologias, bem como se pensar um novo projeto pedagógico visando o respeito pelas limitações 
destes alunos, como ainda a uma prática que incentive este aluno a desenvolver as competências necessárias para sua escolarização.

Por fim vários fatores influenciam na escolarização do aluno com deficiência intelectual nas turmas regulares, a literatura nos mostra várias dificuldades em incluí-los bem como de fato escolarizarem estes alunos. Estas dificuldades perpassam pelas estruturas físicas e curriculares da escola, como também pela formação de professores.

Isso implica necessariamente um trabalho colaborativo, não só entre professores da escola regular e do atendimento educacional especializado, mas também entre a escola e a universidade, como centro produtor e difusor de pesquisas.

\section{Considerações finais}

Ter acesso aos cadernos usados pelos alunos de $2^{\circ}$ e $3^{\circ}$ ano nas salas regulares foi a descoberta de uma fonte de pesquisa muito rica quanto as possibilidades de organização, seleção de elementos a destacar e de análise. E por isso nos abriu possibilidades de investigação que o currículo proporciona. Bem como, refletir sobre o valor do caderno de registro utilizado em sala de aula, este objeto que é símbolo da cultura escolar, e exerce a função de guardar informações que têm um potencial para além de suprir a memória para exames e notas, mas também de revelar informações que normalmente seriam "engavetadas".

Da mesma forma, no decorrer desta pesquisa foi possível notar o quanto as discussões a respeito da acessibilidade curricular para alunos com deficiência ainda são ocupadas em grande parte por determinações políticas da perspectiva inclusiva. Longe de descredenciar a importância desses estudos, acreditamos que é possível partir destes para ampliar o repertório de discussões, permitindo ao processo de inclusão já existente a possibilidade de se ter condições de evoluir e agregar ao processo de formação de professores e professoras que vivenciam demandas tão urgentes no universo de suas salas de aula. 
Também por isso, este trabalho confronta a lógica de organização, característica do processo de escolarização, por anos, no qual cada grupo pertence a mesma faixa etária e por isso pode vir a partilhar outras características de interesse, comportamento e/ou ensino e aprendizagem. Demonstrando a necessidade de se contextualizar e resignificar os conteúdos/atividades acessados por todos os alunos para chegar ao objetivo de progresso no decorrer do ano letivo e entre os anos que compõem o primeiro ciclo de alfabetização no Ensino Fundamental da escola básica regular.

Criar mecanismos de democratização da escola e do conhecimento, perpassa pelo processo de redefinição das práticas curriculares, referindo-se a respeito dos processos de seleção e organização dos conteúdos escolares. A lacuna existente entre a prescrição curricular e o currículo em ação, é uma lacuna que precisará ser investigada posteriormente.

A despeito disso, no fim das contas, o problema não está na escolarização de alunos com deficiência, mas na própria forma como a escolarização vem sendo desenvolvida, implicando na democratização de acesso ao conhecimento escolar, nas suas múltiplas formas, e podendo garantir a estes sujeitos uma efetiva inclusão social, uma vez que dominando estes conhecimentos aumenta-se a possibilidade de participar da sociedade e da produção material.

\section{Referências}

ANDRÉS, M. M. P.; ZAMORA, S. R. Representações da escola e da cultura escolar nos cadernos infantis (Espanha, 1922-1942). In: VENANCIO, A. C.(org.). Cadernos à vista: escola, memória e cultura escrita. Rio de Janeiro: EdUERJ, 2008.

BARDIN, L. Análise de conteúdo. Edições 70, 2009.

BELÉM. Programa de formação continuada de professores: alfabetização, letramento e matemática. SEMEC-PA/ECOAR, 2012. 
BRASIL. Declaração de Salamanca: Sobre Princípios, Políticas e Práticas na Área das Necessidades Educativas Especiais. ONU, Salamanca/Espanha, 1994.

BRASIL. Declaração Mundial sobre Educação para Todos: plano de ação para satisfazer as necessidades básicas de aprendizagem. UNESCO, Jomtiem/Tailândia, 1990.

BRASIL. Constituição de 05 de outubro de 1988. Constituição da República Federativa do Brasil de 1988. Brasília, DF, 05 out 1988. Disponível em: <http://www.planalto.gov.br/ccivil_03/Constituicao/Constitui\%C3\%A7ao.htm >. Acesso em: 05/03/2019.

BRASIL. Ministério da Educação. Lei de Diretrizes e Bases da Educação Nacional. LDB, 9.394 de 20 de dezembro de 1996.

BRASIL. Política Nacional de Educação Especial na Perspectiva da Educação Inclusiva. Secretaria de Educação, 2008.

BRASIL, Pacto Nacional pela Alfabetização na Idade Certa: A alfabetização de crianças com deficiência: uma proposta inclusiva. Secretaria de Educação Básica/MEC, 2012.

BRASIL. Resolução $n^{\circ}$ 7, de dezembro de 2010: fixa diretrizes curriculares nacionais para o ensino fundamental de nove anos. CNE/CEB. Diário oficial da União, 2010.

BRASIL. Lei no 13.005, de 25 de junho de 2014. Aprova o Plano Nacional de Educação e dá outras providências. Brasília, DF, 25 jun. 2014. Disponível em: <http://www.planalto.gov.br/ccivil_03/_Ato2011-2014/2014/Lei/L13005.htm $\geq$. Acesso em: 06/02/2019.

CUNHA, É. V. R. da. O Currículo e o seu planejamento: concepções e práticas. Espaço do currículo, v.3, n.2, p.578-590, setembro de 2010 a março de 2011.

CURY, C. R. J. A educação básica no brasil. Educação e Sociedade. Campinas, vol. 23, n. 80, setembro/2002, p. 168-200.

DUARTE, N. Os conteúdos escolares e a ressureição dos mortos: contribuições à teoria histórico-critica. Campinas, SP: Autores Associados, 2016.

FARIA FILHO, L. M. Escolarização, cultura e práticas escolares no Brasil: elementos teóricos-metodológicos de um programa de pesquisa. In: LOPES, A. C.; MACEDO, E. (Orgs.). Disciplina e Integração curricular: História e políticas. Rio de Janeiro: DP\& A, 2002. 
GABRIEL, C. Conhecimento escolar: objeto incontornável da agenda política educacional contemporânea. Revista Educação em Questão, Natal, v. 45, n. 31, p. 82-110, jan./abr. 2013.

GAMBOA, S. S. Tendências epistemológicas: dos tecnicismos e outros "ismos" aos paradigmas científicos. In: GAMBOA, S. S.; SANTOS FILHO, José C.

Pesquisa Educacional: quantidade-qualidade. $6^{a}$ ed. São Paulo: Cortez, 2007. (Coleção Questões da Nossa Época; v. 42).

\section{LIBÂNEO, J. C. Didática. São Paulo: Cortez, 1994.}

LUNARDI-MENDES, G. M. A função social da escolarização básica: reflexões sobre as práticas curriculares da escola. In: VIII Congresso Luso-afro-brasileiro de Ciências Sociais - A Questão Social no Novo Milénio, Coimbra, 2004.

MENDES, G. M. L; SILVA, F. de C. T. Currículo e conhecimento escolar na contemporaneidade: desafios para a escolarização de sujeitos com deficiência. In: Dossiê Educação Especial: diferenças, currículo e processos de ensino aprendizagem. v. 22, n. 80, 11 de agosto de 2014. Disponível em: <http://dx.doi.org/10.14507/epaa.v22n80.2014>. Acesso em: março 2019.

MIGNOT, A. C. V. Antes da escrita: uma papelaria na produção e circulação de cadernos escolares. In: VENANCIO, A. C. (org.). Cadernos à vista: escola, memória e cultura escrita. Rio de Janeiro: EdUERJ, 2008.

PLETSCH, M.; MENDES, G.; HOSTINS, R. Observatórios de Educação Especial: Políticas públicas, práticas e avaliação escolar. In: Revista Teias v. 17, n.46, jul./set. - 2016. Disponível em: <https://www.epublicacoes.verj.br/index.php/revistateias/article/view/25495/18544>. Acesso em: jan. 2019.

ROLDÃO, M. do C. Função docente: natureza e construção do conhecimento profissional. Revista Brasileira de Educação v. 12 n. 34 jan./abr. 2007.

SACRISTÁN, J. G. O currículo: os conteúdos do ensino ou uma análise prática? In: SACRISTÁN, J. G; PEREZ GÓMEZ, A. I. Compreender e transformar o ensino. $4^{\mathrm{a}}$ ed. Porto Alegre: ArtMed, 1998.

SAMPAIO, C. T. Convivendo com a diversidade: a inclusão da criança com deficiência intelectual segundo professoras de uma escola pública de ensino fundamental. 2005. 151 f. Dissertação (Mestrado em Psicologia) - Faculdade de Filosofia e Ciências humanas, Universidade Federal da Bahia, Salvador, 2005.

SANTOS, A. C. N. SOUZA, V. R. M. O paradigma da educação especial em escolas municipais de ensino fundamental na cidade de Aracajú na área da 
Educação Física. In: Revista Tempo e Espaço em Educação. Aracajú: Editora Diário Oficial, 2011.

SANTOS, L. Seleção do conhecimento escolar. Salto para o futuro - Currículo: conhecimento e cultura. Ano XIX - No 1 - Abril/2009.

SAVIANI, D. Pedagogia histórico-crítica: primeiras aproximações. 8. ed. rev. e ampl. Campinas: Autores Associados, 2003.

SILVA, F. de C. T. Estudo de documentos curriculares locais e suas Implicações para a Construção da diferenciação/flexibilização curricular (1998-2008).

Revista e-curriculum, São Paulo, v. 8. n. 2. Ago., 2012.

TELES, S. M. O professor no processo de inclusão de alunos com deficiência intelectual: um estudo sobre os significados construídos no fazer pedagógico. 2010. 132 f. Dissertação (Mestrado de psicologia) - Instituto de Psicologia, Universidade de Brasília, Brasília, 2010.

Recebido em: 01 de abril de 2020

Aprovado em: 22 de Junho de 2020 Publicado em: 01 de setembro de 2020 